\title{
LITERASI KAWASAN SOSIOLOGI MAHASISWA DALAM MEMPERSIAPKAN KARYA AKHIR PROGRAM STUDI PENDIDIKAN SOSIOLOGI FKIP UNTAN
}

\author{
Rustiyarso \\ Prodi Pendidikan Sosiologi, FKIP Untan, Pontianak \\ E-mail : rustiyarso@yahoo.co.id
}

\begin{abstract}
This study aimed to describe the education of sociology departement literacy used by students of sociology of education in preparing the final work in FKIP Tanjungpura University of. The method used is descriptive method survey form with a qualitative approach. Data collected by the indirect communication. Data collection tool used is a questionnaire and documentation in the form outline and design student research. The population of this study were all students of sociology of education that has been qualified in completing course credits a number of 110-115 credits and be eligible to apply for the title of the research to the academic supervisor. The research proves that students in general education courses sociology "in line" in preparing for the writing of the final work through the proposed outline and the design of the proposed research to the academic supervisor or to the sociology of education courses. In particular: 1) student of the sociology of education before writing her college thesis to perform a wide variety of approaches and work hard to get a variety of literacy suite of social media both print and non-print; 2) student education study program of sociology in doing literacy courses to prepare for the final works in sociology of education courses to experience various obstacles whether they are economic, technical as well as non-economic and non-technical; 3) the strategies used to overcome various obstacles in literacy preparation was writing the end of college students of education and sociology are doing searching brawshing using a web search engine sociology department, namely Google and Yahoo and other web search engines.
\end{abstract}

Keywords: literacy, education of sociology, end of college preparatory works

\section{PENDAHULUAN}

Berkenaan dengan masalah literasi ada sebuah laporan penelitian yang menempatkan Indonesia pada posisi 60 dari 61 negara. Indonesia hanya setingkat lebih tinggi dari Botswana, sebuah negara miskin di Afrika. Penelitian di bidang literasi yang dilakukan Central Connecticut State University di New Britain, Conn, Amerika Serikat, menempatkan lima negara pada posisi terbaik yaitu Finlandia, Norwegia, Islandia, Denmark, dan Swedia (The Jakarta Post, 12 Maret 2016). Hasil penelitian di atas menunjukkan betapa lemahnya budaya literasi dalam masyarakat Indonesia. Fakta menunjukkan bahwa sebagian besar orang termasuk mahasiswa masih mengandalkan apa yang dilihat dan didengar dalam berpikir, bersikap, dan bertindak.

Berdasarkan sensus Badan Pusat Statistik (BPS), seperti ditulis selasar.com (29-52015, pada tahun 2006) menunjukkan $85,9 \%$ masyarakat memilih menonton televisi daripada mendengarkan radio $(40,3 \%)$ dan membaca koran $(23,5 \%)$. Hal ini menandakan bahwa masyarakat (termasuk mahasiswa ) ditengarai belum terbiasa melakukan sesuatu berdasarkan pemahaman dari membaca. Pada gilirannya berimbas pada cara berpikir dan bertindak orang belum dapat mengaktualisasikan diri melalui tulisan. Membaca dan menulis belum 
mengakar kuat dalam budaya bangsa, dan hal ini juga ditemukan di kalangan civitas akademika termasuk mahasiswa. Masyarakat lebih sering menonton atau mendengar dibandingkan membaca apalagi menulis.

Berdasarkan sensus Badan Pusat Statistik (BPS), seperti ditulis selasar.com (29-52015, pada tahun 2006) menunjukkan 85,9 \% masyarakat memilih menonton televisi daripada mendengarkan radio $(40,3 \%)$ dan membaca koran $(23,5 \%)$. Hal ini menandakan bahwa masyarakat (termasuk mahasiswa) ditengarai belum terbiasa melakukan sesuatu berdasarkan pemahaman dari membaca. Pada gilirannya berimbas pada cara berpikir dan bertindak orang belum dapat mengaktualisasikan diri melalui tulisan. Membaca dan menulis belum mengakar kuat dalam budaya bangsa, dan hal ini juga ditemukan di kalangan civitas akademika termasuk mahasiswa. Masyarakat lebih sering menonton atau mendengar dibandingkan membaca apalagi menulis.

Berdasarkan sensus Badan Pusat Statistik (BPS), seperti ditulis selasar.com (29-52015, pada tahun 2006) menunjukkan 85,9\% masyarakat memilih menonton televisi daripada mendengarkan radio $(40,3 \%)$ dan membaca koran $(23,5 \%)$. Hal ini menandakan bahwa masyarakat (termasuk mahasiswa) ditengarai belum terbiasa melakukan sesuatu berdasarkan pemahaman dari membaca. Pada gilirannya berimbas pada cara berpikir dan bertindak orang belum dapat mengaktualisasikan diri melalui tulisan. Membaca dan menulis belum mengakar kuat dalam budaya bangsa, dan hal ini juga ditemukan di kalangan civitas akademika termasuk mahasiswa. Masyarakat lebih sering menonton atau mendengar dibandingkan membaca apalagi menulis.

Berdasarkan fakta empiris dan pengalaman peneliti selaku akademisi yang sudah sering melakukan pembimbingan karya akhir pada mahasiswa program studi pendidikan sosiologi, Jurusan Pendidikan Ilmu-Ilmu Sosial FKIP Untan dalam persiapan menulis karya akhir mahasiswa yang berupa skripsi banyak yang kurang memahami pentingnya literasi. Apalagi literasi yang berkenaan dengan kawasan sosiologi. Pertanyaan mengapa dapat terjadi hal tersebut? Mengapa belum terbiasa membaca menulis (literasi) ? Secara umum, berikut ini yang diduga menjadi salah satu dari beberapa faktor penyebab yang melatarbelakangi. Latar belakang ini dipahami sebagai sebuah kondisi faktual yang ada saat ini dalam masyarakat termasuk di program studi pendidikan sosiologi FKIP Untan.

Pertama, kesadaran yang sangat rendah tentang pentingnya membaca. Mahasiswa beranggapan membaca hanya menghabiskan waktu. Membaca tak mendatangkan manfaat atau keuntungan. Lebih baik bekerja, jelas menghasilkan uang. Padahal bekerja apa pun membutuhkan bacaan. Bacaan yang terkait dengan pekerjaan tentunya. Keyakinan seperti itu juga ada di kalangan sebagian besar besar mahasiswa yang diglongkan sebagai kelompok masyarakat terpelajar. Mahasiswa membaca hanya saat jelang ujian. Sebab itu bermanfaat untuk mendapat nilai baik dari dosen. Mahasiswa tak mau membaca untuk kepentingan yang lain. Kedua, harga buku mahal, minim perpustakaan. Harga buku yang sangat mahal membuat tak banyak orang mampu membeli buku. Lebih dari itu, membeli buku tidak dianggap sebagai kebutuhan. Apalagi bila hal itu dibandingkan dengan kebutuhan pokok. Jelas, buku dikesampingkan. Membeli buku hanya saat kuliah, itu pun tidak semua mahasiswa melakukan. Oleh karena itu hanya sebagian kecil, anggota masyarakat yang mampu dan mau gemar membaca. Demikian pula untuk para siswa (pelajar SD, SLTP, SLTA), dimana selaku peserta didik di sekolah ini seringkali hanya mengandal buku paket.

Di samping itu, ada faktor keterbatasan jumlah perpustakaan di tingkat universitas maupun lingkungan tingkat akultas (termasuk FKIP Untan) berikut dengan koleksi yang disediakan untuk dibaca atau dipinjam relatif juga masih sedikit dan banyak yang tidak up to date alias sudah ketinggalan. Berdasarkan fakta tambahan pula bahwa di setiap kabupaten/kota hanya ada satu perpustakaan daerah dimana tidak semua sekolah memiliki. Perpustakaan yang ada di tingkat universitas maupun tingkat fakultas belum terkelola secara baik ditinjau dari berbagai aspek. Di antaranya, stok jumlah 
buku terbatas, hal ini berimbas pada peminat dari kalangan mahasiswa maupun civitas akademika lain menjadi berkurang, dengan demikian berimbas pada kondisi perpustakaan menjadi sepi pengunjung.

Ketiga, penghargaan sangat minim terhadap karya tulis. Menulis tidak memperoleh apa-apa selain membuang waktu dan energi. Persepsi khalayak seperti itu bukan tanpa alasan. Sebab dari menulis, secara materi apa yang diperoleh tak sebanding dengan keringat yang keluar. Itu gambaran keadaan dunia tulis menulis di negeri ini. Tidak ada penghargaan yang setimpal untuk para penulis. Bangsa Indonesia belum bisa menghargai karya ilmiah seperti menulis. Oleh karena itu, tak heran jika sedikit orang yang bercita-cita menjadi penulis termasuk di kalangan civitas akademika. Hanya personal civitas akademika yang masih memiliki idealisme tinggi yang mau menulis.

Berkaitan dengan persiapan menulis karya akhir mahasiswa program studi pendidikan sosiologi yang berupa skripsi seharusnya sudah memiliki literasi kawasan keilmuan di program studi yang bersangkutan. Namun, fakta dari mahasiswa yang mengajukan outline judul maupun masalah penelitian untuk karya akhir mahasiswa dalam bentuk skripsi menunjukkan masih banyak mahasiswa yang belum memahami secara jelas ruang lingkup kawasan keilmuan sosiologi, pendidikan sosiologi maupun sosiologi pendidikan.

Hal ini menurut peneliti sementara diduga belum ada payung penelitian yang menjadi rujukan mahasiswa program studi pendidikan sosiologi. Literasi kawasan sosiologi ini dimaksudkan untuk memberikan arah yang jelas kemana sebenarnya mahasiswa program studi pendidikan sosiologi meneliti, apa yang diteliti, mengapa diteliti, dan bagaimana cara meneliti. Payung penelitian program studi pendidikan sosiologi paling tidak idealnya untuk memberikan kejelasan penjabaran ada hubungan antara pencapaian visi dan misi di tingkat universitas, tingkat fakultas (FKIP) dan di tingkat program studi pendidikan sosiologi merupakan benang merah dan sebagai satu kesatuan yang utuh sehingga dapat mewujudkan visi dan misi program studi pendidikan sosiologi sebagaimana mestinya.

Ada fakta yang sering peneliti temukan dan masih ada kesimpang siuran berupa ide pemikiran, konsep yang tumpang tindih (misconception), maupun antara topik-topik penelitian yang diajukan oleh mahasiswa dimana semestinya tidak diteliti mahasiswa prodi pendidikan sosiologi karena menjadi kawasan program studi pendidikan lain (seperti : pendidikan ekonomi, pendidikan ips, pendidikan geografi, dan pendidikan sejarah serta prodi yang lainnya) malahan diteliti oleh mahasiswa program studi pendidikan sosiologi dalam penulisan karya akhir mahasiswa, dan hal ini disetujui dan/atau dibiarkan oleh pembimbing akademik maupun disahkan pimpinan program studi pendidikan sosiologi.

Berdasarkan uraian singkat yang peneliti paparkan dalam latar belakang penelitian ini diberikan judul : "Literasi Kawasan Sosiologi Mahasiswa Dalam Mempersiapkan Karya Akhir Program Studi Pendidikan Sosiologi FKIP Untan. "6

\section{METODE PENELITIAN}

Penelitian ini menggunakan metode deskriptif dalam bentuk survei dengan pendekatan kualitatif. Sumber data penelitian terdiri dari data primer dan sekunder. Satori dan Komariah (2011:103) berpendapat bahwa " sumber data primer adalah sumber data yang langsung memberikan data kepada peneliti”. Sumber data primer penelitian ini adalah data yang diperoleh dari hasil pengumpulan sejumlah responden dalam bentuk kuesioner yang telah diisi secara lengkap, kemudian dilakukan peneliti: editing, tabulasi dan dianalisis serta diinterpretasi oleh peneliti berkenaan dengan masalah literasi kawasan sosiologi yang dilakukan mahasiswa program studi pendidikan sosiologi dalam rangka mempersiapkan penulisan karya akhir kuliah berupa outline atau desain penelitian yang diajukan kepada dosen pembimbing akademik. Sedangkan sumber data sekunder dalam penelitian ini adalah hasil dokumentasi yang dikumpulkan peneliti dalam bentuk buktibukti fisik berupa : desain penelitian atau outline penelitian tertulis yang telah diajukan mahasiswa program studi pendidikan sosiologi kepada 
pembimbing akademik (PA) maupun kepada program studi pendidikan sosiologi. Hal ini sesuai dengan pendapat Sugiyono (2008:225) bahwa"sumber data sekunder merupakan sumber yang tidak langsungmemberikan data kepada pengumpul data".

\section{Teknik Pengumpulan Data Teknik Komunikasi Tidak Langsung}

Berkenaan dengan teknik komunikasi tidak langsung, dalam penelitian ini karena menyangkut pendidikan maka salah satu media yang peneliti lakukan untuk mengumpulkan data yang paling dibutuhkan berkaitan dengan literasi kawasan sosiologi ini adalah digunakan melalui kuesioner atau angket. Hal ini sesuai dengan pendapat Sukardi (2004:76), bahwa "kuesioner adalah alat pengumpul data yang berisi sejumlah pertanyaan yang berhubungan erat dengan masalah penelitian yang hendak dipecahkan, disusun, dan disebarkan ke responden untuk memperoleh informasi di lapangan“. Oleh karena itu, agar tingkat pengembalian kuesioner yang tinggi ini, peneliti sudah merencanakan strategi yang tepat sedemikian rupa sehingga tingkat pengembalian kuesioner tersebut relatif tinggi.

\section{Teknik Dokumentasi ( bibliografi )}

Cara lain yang peneliti lakukan dalam penelitian ini adalah berusaha memperoleh data dari responden dengan teknik dokumentasi. Pada teknik ini, peneliti meyakini mendapatkan informasi dari bermacam-macam sumber tertulis atau dokumen yang adfa pada responden atau tempat, dimana responden bertempat tinggal atau melakukan kegiatan sehari-harinya. Sumber dokumen yang ada dalam penelitian ini peneliti membagi dua macam, yaitu dokumen resmi, berupa surat keputusan, surat instruksi, dan surat bukti kegiatan yang telah dikeluarkan oleh pihak program studi, jurusan maupun fakultas, yang dalam hal ini program studi pendidikan sosiologi, jurusan PIIS dan FKIP Untan. Sedangkan dokumentasi tidak resmi dapat berupa surat nota, surat pribadi yang memberikan informasi kuat terhadap kejadian berkenaan dengan masalah literasi kawasan sosiologi yang dilakukan oleh para mahasiswa program studi pendidikan sosiologi. Hal ini sesuai dengan pendapat Hadari Nawawi (2007:101) bahwa teknik dokumenter adalah “ cara mengumpulkan data yang dilakukan dengan katagori dan klasifikasi bahan-bahan tertulis yang berhubungan dengan masalah penelitian, baik dari sumber dokumen maupun buku-buk, koran, majalah dan lain-lain”.

\section{Alat Pengumpul Data \\ Kuesioner}

Dalam penelitian survei tentang literasi kawasan sosiologi di kalangan mahasiswa program studi pendidikan sosiologi dalam rangka mempersiapkan karya tulis akhir kuliah, dalam bentuk item- item pertanyaan tertutup. Sebab peneliti dalam hal ini telah menyediakan beberapa alternatif jawaban yang cocok bagi responden. Pada kuesioner ini peneliti dengan sengaja telah memberikan beberapa alternatif jawaban yang pada kolom yang disediakan, sementara responden tinggal memilih dari jawaban yang ada yan paling mendekati pilihan responden. Kuesioner dengan item tertutup ini pada prinsipnya menurut peneliti efektif demi kepentingan peneliti, karena dengan hanya memberikan alterntatif jawaban, responden lebih dapat membawa jawaban sesuai dengan tujuan penelitian ini.

\section{Panduan Dokumentasi}

Dokumentasi adalah salah satu metode pengumpulan data dengan melihat atau menganalisis dokumen-dokumen yang dibuat oleh subyek sendiri atau orang lain tentang subyek (Herdiansyah, 2011:143). Dokumentasi dalam hal ini digunakan peneliti untuk mendapatkan gambaran dari sudut pandang subyek melalui media tertulis dan dokumen lainnya yang ditulis ata dibuat langsung oleh subyek yang bersangkutan. Berdasarkan penjelasan ini, penggunaan dokumentasi dalam penelitian ini dimaksudkan sebagai bukti otentik atau rekam jejak yang bersifat tertulis dan tergambarkan (foto-foto). Data yang dikumpulkan dengan alat dokumentasi ini peneliti sebut sebagai data sekunder. Dimaksudkan untuk memberikan informasi dan kejelasan tambahan atau pelengkap secara tidak langsung, di antaranya tulisan-tulisan, 
arsip-arsip usulan outline, desain penelitian yang berkaitan dengan literasi kawasan sosiologi mahasiswa dalam mempersiapkan penulisan karya akhir kuliahnya.

\section{Teknik Analisis Data}

Adapun teknik analisis data yang digunakan dalam memaknai data yang terkumpul oleh peneliti dengan dua model analisis kualitatif. Analisis kualitatif data dideskripsikan sesuai dengan situasi dan kondisi yang ada, sedangkan analisis kuantitatif digunakan alat bantu olah data statistik deskriptif. Untuk mengetahui kejelasan informasi mengenai literasi yang digunakan oleh para responden, dalam hal ini adalah mahasiswa prodi pendidikan sosiologi jurusan PIIS FKIP Untan Pontianak digunakan teknik analisis deskriptif dengan kriteria ideal yaitu : mean ideal dan standar deviasi ideal. Kriteria yang digunakan adalah dengan mendasarkan formulasi rumus : $\mathrm{Mi}=(\mathrm{ST}+\mathrm{SR})$ dan $\mathrm{Sdi}=(\mathrm{ST}-\mathrm{SR})$. Adapun penjelasannya $: \mathrm{Mi}=$ mean ideal $; \mathrm{Sdi}=$ standar deviasi ideal ; ST $=$ Skor tertinggi ; $\mathrm{SR}=$ skor terendah. Skor ideal tertinggi dan skor terendah diperoleh dari penjumlahan skor masing-masing variabel. Skor terendah setiap butir atau item pertenyaan 1 dan skor tertinggi 4 . Berdasarkan hasil perhitungan mean ideal dan standar deviasi ideal dikatagorikan dengan menggunakan panduan sebagai berikut :

Tabel 1. Panduan Kesesuaian Literasi Dengan Kawasan Sosiologi

\begin{tabular}{ccc}
\hline No & Katagori & Rentang \\
\hline 1 & Sangat sesuai & $\geq \mathrm{Mi}+(1,5 \times$ Sdi $)$ \\
\hline 2 & Sesuai & Mi sampai Mi $+(1,5 \times$ Sdi $)$ \\
\hline 3 & Mendekati sesuai & Mi $-(1,5 \times$ Sdi $)$ sampai $($ Mi $)$ \\
\hline 4 & Tidak sesuai & $<$ Mi $+(1,5 \times$ Sdi $)$ \\
\hline
\end{tabular}

Selanjutnya untuk mendeteksi deskripsi nilai rata-rata, tertinggi maupun terendah digunakan tabel 1 sebagai acuan alat analisis. Untuk menjawab total keseluruhan dari hasil angket tentang kesesuaian literasi yang digunakan mahasiswa prodi pensos selaku responden penelitian yaitu berkaitan dengan kawasan pendidikan sosiologi dalam menyusun karya akhir digunakan rumus rerata ( mean ). Jumlah semua nilai $\left(\sum X\right)$; X $=$ rata-rata ; $\mathrm{N}=$ jumlah subyek keseluruhan ( populasi ) $; \mathrm{n}=$ jumlah sampel. Oleh karena itu untuk pengujian keabsahan data peneliti melakukan beberapa tindakan reduksi data, display data, verifikasi dan simpulan sementara terhadap data yang telah terkumpul di mana sebelumnya juga dilakukan tindakan validasi sehingga secara keseluruhan prosedur dan metode penelitian survai ini tidak dilanggar.

\section{HASIL DAN PEMBAHASAN Hasil Penelitian}

Penelitian ini sengaja dilakukan oleh peneliti untuk mengetahui kejelasan informasi terhadap sejumlah mahasiswa program studi strata satu pendidikan sosiologi pada jurusan PIIS FKIP Universitas Tanjungpura Pontianak dalam hubungannya dengan literasi penulisan karya akhir. Hal ini dipandang perlu oleh peneliti untuk dianalisis, apakah para mahasiswa sebelumnya mengetahui cara-cara dan strategi dalam melakukan persiapan-persiapan yang dipandang relevan dalam literasi kawasan pendidikan sosiologi atau sosiologi pendidikan sebelum menyusun karya akhir kuliah.

Selama kurang lebih delapan tahun atas pendirian program studi strata satu ini (2008 s.d 2016) belum ada satu kajian akademik yang spesifik melalui penelitian oleh pejabat maupun para pendidik di program studi pendidikan sosiologi untuk melakukan sejumlah pengecekan relevansi dan / atau analisis literasi tentang kawasan pendidikan sosiologi atau sosiologi pendidikan kepada para mahasiswa dalam menyusun karya akhir kuliah.

\section{Data Literasi Kawasan Pendidikan Sosiologi}

Berdasarkan hasil data yang diperolah peneliti atas sampel menunjukkan bahwa responden 
dalam persiapan untuk menyusun karya akhir kuliah sangat variatif. Artinya dalam penelitian ini ditemukan ada sampel yang melakukan literasi sebelumnya dengan baik maupun ada sampel yang belum melakukan literasi sepenuhnya dengan baik untuk mengetahui tentang ruang lingkup kawasan pendidikan sosiologi yang telah dipersyaratkan oleh program studi pendidikan sosiologi. Persyaratan yang dimaksud dalam hal ini adalah kajian-kajian akademik yang berhubungan dengan pendidikan sosiologi atau sosiologi pendidikan pada karya akhir kuliah responden.

Berikut ini disajikan data dalam bentuk beberapa tabel variasi data literasi sampel dan kesesuaian literasi kawasan sosiologi dalam melakukan persiapan penyusunan karya akhir kuliah mahasiswa.

Tabel 2. Data Responden Dengan Persiapan Menyusun Karya Akhir Kuliah

\begin{tabular}{ccccc}
\hline No & Keterangan & $\begin{array}{c}\text { Frekuensi } \\
(\text { orang) }\end{array}$ & $\begin{array}{c}\text { Persentase } \\
(\mathbf{\%})\end{array}$ & Katagori / Indikator \\
\hline 1 & $\begin{array}{c}\text { Melakukan literasi } \\
\text { sebelum menulis }\end{array}$ & 17 & 85 & Sesuai \\
\hline 2 & $\begin{array}{c}\text { Belum sepenuhnya } \\
\text { melakukan literasi }\end{array}$ & 3 & 15 & Belum sesuai \\
\hline 3 & Tidak melakukan literasi & 0 & - & - \\
\hline & Jumlah & 20 & 100 & \\
\hline
\end{tabular}

Sumber data : data primer, diolah, 2016

Tabel 3 Data Arahan Kawasan oleh Dosen PA ( pembimbing akademik)

\begin{tabular}{ccccc}
\hline No & Keterangan & $\begin{array}{c}\text { Frekuensi } \\
\text { (orang) }\end{array}$ & $\begin{array}{c}\text { Persentase } \\
(\%)\end{array}$ & Katagori / Indikator \\
\hline 1 & $\begin{array}{c}\text { PA memberikan arahan } \\
\text { tentang kawasan sosiologi } \\
\text { dengan jelas dan rinci }\end{array}$ & 14 & 70 & $\begin{array}{c}\text { Ketika sudah /sedang } \\
\text { dalam konsultasi tentang } \\
\text { judul outline/desain }\end{array}$ \\
\hline 2 & $\begin{array}{c}\text { PA belum memberikan } \\
\text { arahan tentang kawasan } \\
\text { dengan jelas dan rinci }\end{array}$ & 3 & 15 & Sda \\
\hline 3 & $\begin{array}{c}\text { PA tidak memberikan } \\
\text { arahan tentang kawasan } \\
\text { dengan jelas dan rinci }\end{array}$ & 3 & 15 & Sda \\
\hline & 20 & 100 & \\
\hline
\end{tabular}

Sumber data : data primer, diolah, 2016.

Tabel 4. Data Pengetahuan Ruang Lingkup Kawasan Responden

\begin{tabular}{ccccc}
\hline No & Keterangan & $\begin{array}{c}\text { Frekuensi } \\
\text { (orang) }\end{array}$ & $\begin{array}{c}\text { Persentase } \\
(\mathbf{\%})\end{array}$ & Katagori / Indikator \\
\hline 1 & Tahu sepenuhnya & 19 & 95 & Sesuai harapan mahasiswa \\
\hline 2 & Tahu sebagian saja & 1 & 5 & $\begin{array}{c}\text { Belum sesuai harapan } \\
\text { mahasiswa }\end{array}$ \\
\hline 3 & Belum tahu sepenuhnya & 0 & - & $\begin{array}{c}\text { Tidak sesuai harapan } \\
\text { mahasiswa }\end{array}$ \\
\hline & Jumlah & 20 & 100 & \\
\hline
\end{tabular}

Sumber data : data primer, diolah, 2016. 
Tabel 5. Data Hambatan Literasi Responden tentang Kawasan Sosiologi

\begin{tabular}{ccccc}
\hline No & Keterangan & $\begin{array}{c}\text { Frekuensi } \\
\text { (orang) }\end{array}$ & $\begin{array}{c}\text { Persentase } \\
(\mathbf{\%})\end{array}$ & Katagori / Indikator \\
\hline 1 & Hambatan ekonomis & 14 & 70 & Perlu Biaya relatif tinggi \\
\hline 2 & Hambatan teknis & 2 & 10 & $\begin{array}{c}\text { Perlu kemauan dan } \\
\text { kemampuan akademik }\end{array}$ \\
\hline 3 & $\begin{array}{c}\text { Hambatan non ekonomis } \\
\text { dan non teknis }\end{array}$ & 4 & 20 & $\begin{array}{c}\text { Non biaya dan non } \\
\text { kemampuan akademik }\end{array}$ \\
\hline & Jumlah & 20 & 100 & \\
\hline
\end{tabular}

Sumber data, data primer, diolah, 2016.

Tabel 6 Data Strategi Responden

\begin{tabular}{ccccc}
\hline No & Keterangan & $\begin{array}{c}\text { Frekuensi } \\
\text { (orang) }\end{array}$ & $\begin{array}{c}\text { Persentase } \\
\mathbf{( \% )}\end{array}$ & Katagori Kawasan Sosiologi \\
\hline $1 \quad \begin{array}{c}\text { Melakukan usaha keras } \\
\text { untuk bisa literasi sebelum } \\
\text { menulis }\end{array}$ & 15 & 75 & $\begin{array}{c}\text { Mencari literatur yang sesuai } \\
\text { dengan cara-cara yang benar } \\
\text { dengan kerja keras }\end{array}$ \\
\hline $2 \quad \begin{array}{c}\text { Belum sepenuhnya } \\
\text { melakukan usaha keras } \\
\text { untuk literasi }\end{array}$ & 3 & 15 & $\begin{array}{c}\text { Belum sepenuhnya mencari } \\
\text { literatur yang sesuai dengan } \\
\text { upaya kerja keras }\end{array}$ \\
\hline 3 & Tidak melakukan literasi & 2 & 10 & Tidak tahu bagaimana \\
\hline sama sekali & & & $\begin{array}{c}\text { mencari literatur yang sesuai } \\
\text { dan belum berupaya dengan } \\
\text { kerja keras }\end{array}$ \\
\hline & & & \\
\hline
\end{tabular}

Sumber data : data primer, diolah, 2016.

Tabel 6. Data Kesesuaian Usulan Responden dalam Literasi Kawasan Sosiologi

\begin{tabular}{cccccc}
\hline $\begin{array}{c}\text { Mahasiswa } \\
\text { Program Studi }\end{array}$ & No & $\begin{array}{c}\text { Skor } \\
\text { riil } \\
\text { responden }\end{array}$ & $\begin{array}{c}\text { Skor } \\
\text { ideal }\end{array}$ & $\begin{array}{c}\text { Persentase } \\
\mathbf{( \% )}\end{array}$ & Katagori \\
\hline & 1 & 60 & 100 & 60 & Sesuai \\
\cline { 2 - 6 } & 2 & 70 & 100 & 70 & Sesuai \\
\hline Literasi Kawasan \\
Sosiologi & 3 & 80 & 100 & 80 & Sangat sesuai \\
\cline { 2 - 6 } & 4 & 45 & 100 & 45 & Tidak sesuai \\
\cline { 2 - 6 } & 5 & 70 & 100 & 70 & Sesuai \\
\hline Jumlah & & $\mathbf{3 2 5}$ & $\mathbf{5 0 0}$ & $\mathbf{6 5}$ & Sesuai \\
\hline
\end{tabular}

Sumber data : data primer, diolah, 2016

\section{Pembahasan}

Berikut ini peneliti lebih menekankan pada pembahasan berkaitan dengan pertanyaanpertanyaan penelitian yang diajukan diawal dalam penelitian survei ini. Berikut ini dilakukan analisis atas hasil temuan peneliti di lapangan saat dilakukan survei dengan cara menyebarkan angket dan mencermati hasil dokumentasi yang berupa : outline maupun desain penelitian mahasiswa di program studi pendidikan sosiologi jurusan PIIS FKIP Untan Pontianak, atas pertanyaan:

1. Mahasiswa program studi pendidikan sosiologi dalam menggunakan literasi untuk menyelesaikan tugas akhir kuliah Realitas budaya atau kebiasaan literasi di jenjang Sekolah Dasar (SD) hingga Perguruan Tinggi( PT), termasuk di prodi pendidikan ekonomi 
jurusan PIIS saat ini memang masih belum sepenuhnya menggembirakan alias masih relatif memprihatinkan. Berbagai persoalan dari sekian banyak persoalan yang dihadapi bangsa Indonesia sekarang ini, yang paling menonjol adalah salah satunya adalah : isu maraknya korupsi, rendahnya literasi, lemahnya daya saing, dan rusaknya manajemen layanan publik. Berbagai pengamat sosial asing menengarai situasi ini sebagai akibat dari sistem pendidikan dan politik kebudayaan Orde Baru yang telah menciptakan iklim budaya anti-intelektual. Dari beberapa telaah terhadap buku-buku teks IPS tingkat SD sampai dengan SMU, Niels Mulder (2000:108) dalam Indonesian Images: The Culture of the Public World, secara kritis dikatakan bahwa:

...intellectuals are new to Indonesia, that there is hardly a tradition of critical thought, that is all just in the making. Besides, the development of a critical discourse is thwarted by censorship, ideological manipulation, and mediocre academic standar $d s . .$. and so ideological hegemony, conceptual confusion and ethical inclination combine in a distinctly anti-intellectual cultural climate.

Dengan demikian, buku-buku teks IPS khususnya selama rezim Orba berperan bukan sebagai media pencerdasan bangsa, melainkan sebagai media propaganda politik yang dikemas dalam materi ajar. Dengan kata lain, buku teks adalah cerminan wacana publik, yakni bagaimana publik direkayasa oleh negara untuk berpikir, bersikap, dan bertindak dalam merespon berbagai isu sosial. Selama kurang lebih 30 tahun informasi dalam buku teks tersebut telah dijejalkan kepada sekian juta anak bangsa, sehingga memunculkan sebuah generasi lembek yang kurang tajam nalarnya, yang dalam istilah Mulder disebut "born to be meek". Lemahnya daya kritis-kreatif mahasiswa Indonesia, termasuk mahasiswa program studi pendidikan sosiologi,jurusan PIIS FKIP Untan Pontianak selama ini terpulang kepada dua hal, yakni pertama, kultur tradisional dan kedua, sistem praktik pendidikan.

Mayoritas mahasiswa berbagai program studi, dalam hal ini mahasiswa Indonesia di dalam negeri maupun luar negeri seringkali menyatakan bahwa pendidikan yang diperoleh di Indonesia seperti tidak membekali mahasiswa memiliki kemampuan berpikir kritis dan menyadari bahwa menulis akademik dan presentasi di depan kelas merupakan tugas akademik yang paling sulit bagi mahasiswa. Kesulitan serupa dialami juga oleh mahasiswa program studi pendidikan sosiologi ini. Ketika responden ini diberikan arahan berkenaan dengan literasi kawasan sosiologi yang harus dilakukan untuk dijadikan kajian karya akhir, maka mahasiswa merasa beruntung jika dilatih mengembangkan kemampuan berpikir kritis ketika membaca teks-sesuatu yang tidak diajarkan di bangku perkuliahan.

Oleh karena itu, sudah semestinya jika seorang dosen pembimbing akademik (PA) di program studi program studi pendidikan sosiologi jurusan PIIS FKIP Untan Pontianak, salah satu tugas pokok dan fungsi yang harus dilakukan adalah memberikan literasi kawasan sosiologi sebagai bimbingan akademik, maupun non akademik kepada mahasiswa. Hal ini dilakukan PA sebagai bentuk dari tanggung jawab pendidikan literasi, baik diminta maupun tidak. Apalagi dosen PA tersebut ber-homebase di prodi pendidikan sosiologi sehingga mengetahui secara jelas apa yang menjadi ruang lingkup dan kawasan kajian di program studi, ketika mahasiswa yang akan dan atau dalam proses mengajukan outline atau desain penelitian itu mengalami kebingungan dan ketidak tahuan isi kawasan pendidikan sosiologi untuk dijadikan rujukan saat menyusun karya akhir kuliah.

Berkenaan dengan pentingnya membangun kecerdasan literasi ini sudah sejak dahulu manusia telah dideskripsi sebagai hewan berpikir. Kemampuan berpikir kritis inilah yang membedakan dengan makhluk lain. Tidak mengherankan jika Rene Descartes (1596-1650) dari kesangsiannya terhadap segala kebenaran itu memunculkan diktum yang terkenal, "cogito ergo sum", yang artinya :" aku berpikir maka aku ada". Persoalannya, apakah berpikir itu menjadi itu menjadi kualitas yang inheren pada setiap manusia (dalam hal ini mahasiswa program studi pendidikan sosiologi ?) atau sekedar lebih sebagai kualitas yang diperoleh lewat upaya tak disengaja ?. Tampaknya, yang disebut terakhirlah yang mendekati kebenaran. 
Erat hubungannya kecerdasan literasi di mana ada bukti, bahwa tujuan pendidikan telah mengeksplisitkan pentingnya kualitas kecerdasan, sebagaimana tertuang dalam Bab II, Pasal 3 UU Republik Indonesia Nomor 20 tahun 2003 tentang Sistem Pendidikan Nasional sebagai berikut: Pendidikan Nasional berfungsi :

Mengembangkan kemampuan dan membentuk watak serta peradaban bangsa yang bermartabat dalam rangka mencerdaskan kehidupan bangsa, bertujuan untuk berkembangnya potensi peserta didik agar menjadi manusia yang beriman dan bertakwa kepada Tuhan Yang Maha Esa, berakhlak mulia, sehat, berilmu, cakap, kreatif, mandiri, dan menjadi warga negara yang demokratis serta bertanggungjawab.

Membaca secara cermat kutipan tujuan pendidikan yang tertuang dalam Undang-Undang Sisdiknas di atas, maka dapat dirtikan bahwa sistem Pendidikan Nasional dinawaitukan atau diniatkan untuk mengembangkan potensi kecerdasan bangsa, dan tanpa pendidikan potensi itu tidak mungkin berkembang secara maksimal. Hal ini pun berarti bahwa tingkat kecerdasan seseorang, masyarakat, dan bangsa akan sangat ditentukan oleh kualitas pendidikan.

Berhubungan dengan kutipan Sisdiknas di atas ada tiga kunci yang banyak disebut dalam perbincangan pendidikan berpikir kritis, yaitu : "kecerdasan", "kreatif", dan "demokratis". Untuk sukses membentuk generasi mahasiswa baru (sebagai generasi muda / penerus bangsa) yang mempunyai nalar kritis yang tinggi, terutama di program studi pendidikan sosiologi jurusan PIIS FKIP Untan Pontianak, ada baiknya budaya berpikir kritis ini perlu dilakukan pengecekan yang dapat dirunut dan dimulai dari lingkup keluarga mahasiswa yang bersangkutan. Dalam hal ini orang tua mahasiswa juga sebagai pendidik kodrati mahasiswa yang bersangkutan, ada baiknya membiasakan reading-habit dengan menyediakan home-library bagi mahasiswa di rumah, didukung di tingkat prodi maupun tingkat jurusan atau fakultas. Mau tidak mau, reading-habit sudah semestinya dimulai dari lingkungan keluarga yang bersangkutan, sebelum si mahasiswa memasuki wilayah di dunia luar rumah dalam hal ini ketika melanjutkan ke perguruan tinggi.

Namun tak sampai di situ saja, orang tua juga sebaiknya menjadi teladan bagi si mahasiswa (anak) untuk mencintai budaya membaca. Sebab saat ini budaya atau kebiasaan membaca dan memiliki kepustakaan mahasiswa lama kelamaan tergerus oleh kebiasaan yang mengarah kepada kebiasaan atau sudah membudaya berupa segala sesuatu dilakukan bukan baca tulis sebagaimana mestinya namun berupa pesan singkat (SMS/EMS/ $M M S$ ) atau bahkan menjadi kebiasaan menonton/ melihat bukan lagi kecintaan membaca dan atau menulis.

Pendidikan dibangun diniati untuk mengubah bangunan pemikiran anak bangsa. Dalam hal ini media (baca social media) yang berperan sebagai dasar untuk merealisasikan tujuan pendidikan adalah kurikulum pendidikan itu sendiri. namun yang salah dipahami atau banyak dilupakan adalah bagaimana mengubah mind-set pendidik (dalam hal ini selaku dosen pembimbing akademik) terlebih dahulu sebelum mengajarkan kepada peserta didik (mahasiswa) untuk mengubah mindset -nya. Adalah nonsense apabila kurikulum pendidikan tinggi berganti berkali-kali, namun mind-set pengajar perguruan tinggi, dalam hal ini para dosen masih banyak yang belum berubah.

Oleh karena itu sedemikian komplek atau rumit, jika membahas ihwal pendidikan, namun tak dapat dipungkiri bahwa pendidikan merupakan hal yang tidak dapat terpisah dengan kehidupan anak Adam, karena pendidikan merupakan tombak pengubah manusia menjadi manusia yang lebih baik, yakni menjadi manusia yang paripurna.

Kembali pada pembentukan kecerdasan dan sikap kritis melalui kegiatan literasi, pertanyaan yang selanjutnya mencuat ke permukaan adalah bagaimana kurikulum di tingkat program studi dapat beraksi untuk menghidupkan budaya literasi dikalangan peserta didik (mahasiswa program studi pendidikan sosiologi) ? Solusi yang dapat penulis tawarkan adalah bagaimana mengembangkan kecerdasan dan sikap kritis melalui kecerdasan literasi yang dikemas melalui penggabungan teori konstruktivis dan pendidikan karakter yang sarat akan nilai-nilai Islami.

Penulis meyakini bahwa semua teori pendidikan mempunyai kelebihan dan di satu sisi 
terdapat kekurangan di sana sini. Satu dari sekian teori yang sangat berpengaruh pada kurikulum pendidikan adalah teori konstruktivis, teori ini berakar pada sebilangan disiplin seperti linguistik, psikologi, sejarah, sains, sosiologi dan filsafat.

\section{Hambatan - hambatan yang dihadapi dan dialami mahasiswa program studi pendidikan sosiologi dalam mempersiapkan karya akhir}

Membahas hambatan literasi dalam penelitian survei di atas ini, peneliti berdasarkan data jawaban angket maupun bukti dokumentasi para mahasiswa yang berupa hard-file berupa outline dan desain penelitian para responden dapat diketahui sebagaimana yang tertuang dalam tabel 5 tentang data hambatan literasi mahasiswa adalah lebih banyak disebabkan sebagian besar berupa hambatan ekonomi yaitu sebesar $70 \%$. Hal ini membuktikan bahwa daya dukung atau daya beli pribadi responden secara ekonomi mahasiswa untuk melakukan kegiatan literasi berupa : pengadaan, dan / atau pembelian bahan-bahan baca, buku-buku teks wajib maupun pilihan relatif harganya tidak terjangkau atau mahal.

Responden sudah semestinya dan seharusnya secara pribadi dapat menyediakan sendiri untuk dapat membeli literatur - literatur yang diwajibkan oleh dosen program studi maupun dosen PA yang berkaitan dengan kawasan sosiologis. Fakta dari data yang dianalisis peneliti, para responden mengakui untuk melakukan sebagaimana penjelasan di atas ternyata hal itu tidak bisa responden semuanya secara gratis. Situasi dan kondisi yang diharapkan mahasiswa selaku responden tersebut, secara favourabel dan teknis berkenaan dengan bahan literasi ini, jika dimungkinkan bisa diakses dan diwujudkan ketika mahasiswa memerlukan bahan-bahan literasi yang sesuai senantiasa tersedia bahkan difasilitasi oleh lembaga perguruan tinggi.

Bahan-bahan literasi yang dibutuhkan mahasiwa seharusnya tersedia dalam jumlah yang memadai rasionya dengan pengguna maupun secara kualitas kemutakhiran bahan literasi itu tersedia secara baik di perpustakaan maupun ruangruang baca, bahkan diharapkan selalu lengkap apa yang menjadi koleksi buku teks, jurnal-jurnal ilmiah, hasil-hasil penelitian dan sejenisnya, baik di tingkat universitas sampai dengan tingkat program studi.Namun, apa yang diharapkan para mahasiswa selaku responden tersebut di atas hampir dapat dikatakan belum terpenuhi oleh institusi perguruan tinggi ini. Dalam hal ini mulai dari tingkat universitas sampai dengan program studi dikarenakan berbagai hal. Salah satunya adalah keterbatasan dana anggaran pembelian barang dan jasa kebutuhan perpustakaan yang kecil, sehingga dianggap sebagai unsur keterbatasan teknis maupun ekonomis, sehingga hal ini menjadi salah satu hambatan literasi secara teknis - ekonomis.

Ada beberapa faktor penyebab keterbatasan atau ketersediaan bahan bacaan literasi yang secara teknis kurang berkualitas belum adanya kemutakhiran bahan literasi yang sesuai dengan kebutuhan tiap-tiap mahasiswa program studi maupun perkembangan ilmu pengetahuan dan teknologi menjadikan layanan literasi kurang terlayani dengan baik.

Setiap mahasiswa di perguruan tinggi, khususnya mahasiswa program studi pendidikan sosiologi berharap untuk disediakan oleh institusi dari tingkat universitas sampai dengan tingkat program studi yang terbatas secara kuantitas maupun kualitas ini pada akhirnya juga menimbulkan hambatan non ekonomis. Hambatan non ekonomis yang dirasakan oleh para responden sebesar $20 \%$ di antaranya adalah : kurang kuat dorongan, motivasi dan daya juang berupa kemauan para responden, bosan, tidak mau kerja keras bahkan cenderung bersifat malas sehingga untuk melakukan literasi juga makin menurun.

Hal ini mengingat apa yang dibutuhkan mahasiswa belum bahkan tidak sesuai dengan kawasan kajian program studinya serta tidak tersedia sebagaimana yang diharapkan bersama civitas akademika ( terutama para mahasiswa) selaku pengguna utama kebutuhan literasi ini.

Adanya keterbatasan bahan-bahan literasi yang dapat diakses di tingkat institusi sampai dengan tingkat program studi oleh mahasiswa yang membutuhkan untuk menulis karya akhir mahasiswa pada gilirannya para mahasiwa mengalami kesulitan untuk melakukan baca tulis (literasi). Kesulitan bahan literasi yang dirasakan oleh para responden pada akhirnya menjadikan para 
mahasiswa memerlukan waktu yang lebih lama dalam menulis karya akhir kuliahnya. Di samping itu, keterbatasan literasi menjadikan secara teknis usulan outline maupun desain penelitian para mahasiswa selaku responden dalam karya akhir yang berkaitan dengan kawasan sosiologi menjadi miskin atau kering terhadap literatur teoretik yang sesuai.

\section{Strategi literasi kawasan pendidikan} sosiologi yang sesuai untuk mahasiswa program studi pendidikan sosiologi dalam menyelesaikan karya akhir.

Membahs strategi literasi dalam penelitian survei ketiga ini, peneliti tetap berdasarkan data yang dikumpulkan peneliti melalui instrumen penelitian berupa angket, dimana diketahui bahwa para responden ketika melakukan strategi dalam mengatasi kesulitan literasi sebagaimana disajikan dalam tabel 6 di atas.

Strategi literasi yang dilakukan responden berkaitan dengan beberapa hambatan yang telah dijelaskan di atas, yaitu dengan tetap melakukan kerja keras dalam mencari literatur yang sesuai sebelum melakukan usulan outline maupun desain penelitian sebagai karya akhir kuliah ( skripsi ). Cara-cara responden mencari literatur dalam rangka literasi yang dilakukan dengan menggunakan fasilitas berbagai media massa cetak maupun non cetak atau elektronik yang bersifat online berupa : koran, majalah, buletin, jurnal-jurnal ilmiah cetak maupun online yang bisa diakses via situs-situs internet yang tersedia dengan bantuan mesin pencari google, yahoo, dan sejenis mesin pencari lain dengan cara searching dan brawshing. Hal ini diakui oleh responden penelitian ini sebesar $75 \%$. Dengan kata lain, relatif cukup dominan strategi ini. Disamping itu, responden sebanyak $15 \%$ masih mengakui bahwa dalam strategi literasi masih belum optimal dalam rangka mencari literatur-literatur yang sesuai dengan kajian kawasan sosiologi bahkan belum melakukan kerja keras untuk mendapatkannya. Hal ini tentu berdampak kepada kecepatan dan ketepatan responden untuk mengusulkan outline maupun desain penelitian dalam rangka menulis karya akhir kuliahnya.

Tidak optimalnya strategi usaha kegiatan literasi tersebut kemungkinan juga disebabkan oleh beberapa faktor, diantaranya faktor : pribadi responden, lingkungan responden maupun faktor non teknis responden lain. Bahkan ada sejumlah mahasiswa sebesar $10 \%$ tidak tahu untuk melakukan tindakan literasi. Responden ini tidak tahu bagaimana mencari literatur yang sesuai dengan cara kerja keras menelusuri perpustakaan di institusi, dan di luar institusi, serta di berbagai media cetak maupun media elektronik.

Hal ini tentu sangat disayangkan oleh berbagai pihak di program studi pendidikan sosiologi,baik dosen, dosen PA maupun pejabat program studi, karena apa yang diusulkan dalam outline maupun desain penelitian seringkali ditolak atau dianggap tidak sesuai, mengingat usulan outline itu hampir dapat dikatakan tidak sesuai dan bukan kajian kawasan sosiologi. Oleh karena itu, pihak PA sudah semestinya dapat memberikan bantuan yang bersifat akademik maupun non akademik, dalam rangka memberikan pencerahan dan membuka wawasan kepada responden yang memiliki karakteristik sedemikian rupa, sehingga dapat dihindari adanya kegagalan studi di program studi pendidikan sosiologi.

\section{SIMPULAN DAN SARAN \\ Simpulan}

Berdasarkan hasil analisis data dan interpretasi data yang telah peneliti lakukan berikut dengan pembahasan dapat ditarik kesimpulan secara umum bahwa literasi kawasan pendidikan sosiologi atau sosiologi pendidikan mahasiswa dalam mempersiapkan karya akhir di program studi pendidikan sosiologi FKIP Untan dapat dibuktikan "sesuai", sebagaimana terdeskripsikan dari hasil analisis data angket didukung dokumentasi sehingga dikatakan positip.

Sedangkan secara khusus juga dapat peneliti simpulkan atas sub-sub pertanyaan penelitian sebagai berikut: (1) Mahasiswa program studi pendidikan sosiologi menggunakan berbagai variasi literasi dalam rangka menyelesaikan tugas akhir kuliah berupa outline atau desain penelitian dengan berbagai pendekatan dalam mengatasi hambatan- hambatan di mana mendapatkan pengarahan yang bersifat akademik, mapun non 
akademik dari para dosen pembimbing akademik (PA), terutama sebelum mengusulkan outline atau desain penelitian untuk di seminarkan; (2) Hambatan-hambatan yang dihadapi dan/atau dialami mahasiswa program studi pendidikan sosiologi dalam mempersiapkan karya akhir, berdasarkan hasil analisis data dan interpretasi yang terkumpul pada saat literasi dilakukan adalah kecenderungan hambatan yang katagorinya adalah bersifat : ekonomis, teknik dan non ekonomi maupun non teknik; (3) Strategi literasi kawasan pendidikan sosiologi yang sesuai untuk digunakan mahasiswa program studi pendidikan sosiologi sebelum menyelesaikan penyusunan karya akhir dilakukan mahasiswa yaitu dengan usaha kerja keras pantang menyerah, meskipun banyak hambatan melalui berbagai sumber media massa cetak maupun media massa non cetak atau media elektronik dengan bantuan mesin pencari google atau yahoo, dan mesin pencari sejenis lain dengan cara searching dan brawshing.

\section{Saran}

Berdasarkan hasil penelitian survei di atas, dan temuan di lapangan maka peneliti perlu memberikan saran kepada pihak- pihak berikut sebagai bahan yang perlu direkomendasi seperti di bawah ini; (1) Dosen di lingkungan program studi pendidikan sosiologi, jurusan PIIS FKIP Untan berikut dengan pejabat di tingkat prodi perlu mensosialisasikan dan mendesiminasikan apa saja yang menjadi literasi kajian kawasan sosiologi yang sesuai sekaligus juga dapat diakses dan diterima dengan baik, dan paham secara akademis, melalui buku panduan mahasiswa maupun media yang representatif lain untuk disampaikan kepada mahasiswa program studi yang akan mengusulkan usulan outline atau desain penelitian; (2) Dosen pembimbing akademik (PA) di program studi pendidikan sosiologi, jurusan PIIS FKIP Untan seharusnya mempunyai tugas pokok dan fungsi yang jelas dan rinci yang diberikan dalam bentuk standar operasional prosedur (SOP) oleh pejabat tingkat program studi dalam hubungannya dengan standar layanan prima kepada mahasiswa bimbingan, sehingga dapat lebih operasional, terukur, dan terarah serta bijak, ketika memberikan layanan bimbingan akademik berkaitan dengan penilian kelayakan usulan kajian kawasan sosiologi yang dapat diteliti mahasiswa sebagai perwujudan pendidikan kecerdasan literasi yang tepat di lingkungan program studi pendidikan sosiologi.

\section{DAFTAR RUJUKAN}

Badan Pusat Statistik (2006), Sensus Penduduk tentang Literasi, Jakarta. Diunduh dari tulisan di selasar.com, 2016

Hadari Nawawi, (2007), Metode Penelitian Bidang Sosial, Yogyakarta: Gajah Mada University Press.

Herdiansyah, Haris, (2011), Metodologi Penelitian Kualitatif untuk Ilmu-ilmu Sosial, Jakarta : Salemba Humanika, Cetakan kedua.

Niels Mulder, (2000), The Culture of the Public World, Jakarta : Indonesian Images. Tp

Satori, Djam'an dan Aan Komariah, (2011), Metodologi Penelitian Kualitatif, Bandung : Alfabeta, Cetakan ketiga.

Sukardi, (2004), Metodologi Penelitian Pendidikan, Kompetensi dan Praktiknya, Jakarta, Bumi Aksara.

Sugiyono, (2008), Metode Penelitian Kuantitatif, Kualitatif, Bandung : Alfabeta

Undang-undang Republik Indonesia Nomor 20 Tahun 2003 tentang Sistem Pendidikan Nasional, Jakarta. 